\title{
Human Behaviours on Domestic Waste Recycling Practice among Urban Households
}

\author{
Hamizah Yakob1', Nurul Rif'ah Afiqah Abd Rauf', \\ Yusfida Ayu Abdullah ${ }^{1}$, Alaa Ahmed Badawi ${ }^{3}$
}

${ }^{1}$ Centre of Studies for Town and Regional, Faculty of Architecture, Planning and Surveying, 42300, UiTM Puncak Alam, Selangor, Malaysia

2 Centre of Postgraduate Studies, Faculty of Architecture, Planning and Surveying, 40450, UiTM Shah Alam, Selangor, Malaysia

${ }^{3}$ Green Space Architects, Khalil Hamada, Sidi Bisher, Al Montazah Region, Alexandria, Egypt

hamizah1204@gmail.com, nurulrifahafiqah@gmail.com, ayunazeri@gmail.com, alaabadawi1993@gmail.com Tel: 012-2221768

\begin{abstract}
The propagation of household recycling is undeniable and thorough. Recycling behaviour among households in urban areas and Malaysia has, however, received less attention. Therefore, the purpose of this preliminary study is to outline the influence that household behaviour is motivated through waste recycling. The survey carried out in six (6) suburbs of Shah Alam using a convenient sampling method to perform a site inventory and questionnaire survey. The findings are affected by the influences of recycling and individual activities representing their contribution to recycling domestic waste.
\end{abstract}

Keywords: Human Behaviour; Domestic Waste Recycling; Waste Generation; Urban Households.

eISSN 2514-751X @ 2020 The Authors. Published for AMER ABRA cE-Bs by e-International Publishing House, Ltd., UK. This is an open access article under the CC BY-NC-ND license (http://creativecommons.org/licenses/by$n c-n d / 4.0 /)$. Peer-review under responsibility of AMER (Association of Malaysian Environment-Behaviour Researchers), ABRA (Association of Behavioural Researchers on Asians / Africans / Arabians) and cE-Bs (Centre for Environment-Behaviour Studies), Faculty of Architecture, Planning \& Surveying, Universiti Teknologi MARA, Malaysia.

DOI: https://doi.org/10.21834/ajebs.v5i17.373 


\subsection{Introduction}

Malaysia is experiencing global issues of waste management, scarcity of land for landfill, weaknesses in recycling government and enforcement, lack of the $3 R$ hierarchy practice, pollution, and rising cost of waste management (Behzad, Ahmad, Saied, Elmira, \& Bin, 2011). There was also an absence of mechanisms and studies focusing on domestic waste for recycling. Separating domestic waste into recyclable items can reduce the mass amount of waste mostly generated from households. It classifies waste reduction based on reducing waste such as unwanted clothes, electronics, gadgets, furniture, newspapers, bottles, and metals. There were many issues related to waste disposal management and particularly mechanism to recycling such as the belief of being sustainable but unfortunately not the practice.

Many people can find it difficult to recycle household goods. Yet, up to this day, waste disposal management issues continue. This situation leads to scarcity of land for landfill and leads to the rising cost of waste management. Other than that, Malaysia is far from being successful in recycling activities than other developing countries with higher recycling rates, such as German, Taiwan, Sweden, and Singapore. Additionally, Fauziah \& Agamuthu (2012) claimed that the public's practice of the Global 3Rs approach is still lacking. Several studies discovered the same issues of recycling (Jereme, Siwar, \& Alam, 2015). Hence, established this study to discuss the global need to protect soil and water and protect resources from pollutants. It is also to meet the Malaysian government's strategy in "strengthening the enabling environment for green growth" through its initiative, such as enhancing awareness to create a shared responsibility.

On that count, this preliminary study aims to investigate the household's understanding of attitudes and behaviours that reflects their contribution towards domestic waste recycling practice. This paper looks forward to appraising human behaviour theory towards the urban environment and its factors and examining the household's way and mechanism towards domestic waste recycling. This study also constructs a recycling framework that relates to human behaviours among urban families. Using the hypothesis that household behaviours are more inclined to domestic recycling, this study conducts a questionnaire survey in six (6) suburbs of Shah Alam as a case study. The research was conducted by focusing on factors that drive households to recycle domestic waste and households' recycling behaviours influenced by the type of accommodation and occupation sector concerning domestic waste recycling.

\subsection{Literature Review}

\subsection{Terminologies and Concept of Recycling}

A better understanding of definitions to avoid confusion throughout this study stated as the survey's main keywords: recycling, domestic waste, and recycling behaviour. The verb recycles, or present participle as recycling is the process of converting waste into reusable material. According to Othman and Yuhaniz (2012), recycling is a process - a series of 
activities that include collecting and sorting waste materials, processing these materials to produce brand new products, and purchasing and using these new products by consumers. In a simple word stated by Kawasaki (2014), domestic waste, which is known as kitchen waste or household waste, is used as household waste. Consists of non-hazardous junk and hazardous waste, this study enlightens the non-hazardous waste such as food waste, paper, box, furniture, e-waste, textiles, plastic, and glass. The term was applied by a recent study from Abas (2014), as any product separated into organic and inorganic waste. Organic waste consists of food waste, garden waste, paper, clothing, and rubber waste. The inorganic waste consists of chemical waste, metal, and glass waste. They supported the previous study on waste management, domestic waste known as trash coming out from household products such as plastic wrapping, yard trimming, furniture, clothes, bottles and cans, magazines, home appliances, electronics, and batteries (Environmental \& Agency, 2015).

In the context of recycling behaviour, Teo (2017) belief there have been calls psychosocial constructs such as attitudes, beliefs, values, instead of socioeconomic variables turned out to be more successful in predicting pro-environmental behaviours. Meanwhile, Johansson (2016) states some different things to consider for recycling to be efficient. The factors imply physical attributes, behavioural habits, information levels, behaviours, and expectations. Nevertheless, demographic patterns and societal standards are also relevant, as are reward programs, strategies, or how mature the recycling community is. The critical goal of waste management is to reduce the volume of waste disposed of in landfills. Hence, the basic 3R (Reduce, Reuse, Recycle) principle encourages collaboration between waste producers, waste collectors, processors, and manufacturers to minimize the amount of waste to be disposed of in landfill sites. Thus, it reduces the pollution generated by landfill sites and saves energy and natural resources (Umar, Sehab, \& Yagnik, 2018). People can recycle nearly all items. However, the recycled material value depends on the local procurement method and the market specifications (Abas, 2014). For this study, the physical composition of recycling is organic such as food waste, garden waste, textiles, paper, and boxes. Meanwhile, inorganic consists of plastic, glass, metal (food cans, cans, aluminum), and unique materials (scrap wood, tires, batteries, computers, cellular phones, and any related).

To make recycling an easy option, the provision of recycling facilities shall be prior such as recycling bins, place them strategically next to trash cans in parks, parking lots, and plazas. Better still, any recycling program such as the local kerbside collection program can collect the waste regularly. Recyclable goods, facilities, and services must be regulated daily to prevent overflowing and increase people's courage to recycle (Zen, Noor, \& Yusuf, 2014). Recycling has opportunities that will help people and even save the world. In their research study, Othman \& Yuhaniz (2012) have put forward five (5) the importance of recycling. Recycling helps protect the environment, conserve limited resources, and promotes energy efficiency in energy consumption, then producing something out of fresh raw material. Next, recycling helps build a strong economy, whereas every cost-reduction, energy efficiency, materials conservation, and government can have considerable savings 
in garbage collection and landfilling costs. Over and above, recycling helps build a community where people band together and build organizations working together in recycling initiatives and free recycling groups.

\subsection{Theory of Planned Behaviour (TPB) Framework}

The literature on recycling behaviour focuses mostly on psychological factors such as attitudes and social norms (Thomas \& Sharp, 2013). Despite the existence of numerous behavioural theories, the Theory of Planned Behaviour (TPB) is the most commonly applied theory to explain the pro-environmental intention and behaviour (Al Mamun, Mohiuddin, Ahmad, Thurasamy, \& Fazal, 2018) and has been used by many researchers in a diverse area such as health, education, consumer behaviour, environment and technology studies (Kumar, 2019). The TPB emphasizes that behaviour refers to a willingness to avoid or perform a particular task, in this case as performing domestic waste recycling (i.e., intention) and the control an individual perceives he or she has over a concerning behaviour (i.e., perceived behaviour control (PBC). According to the TPB, from earlier to recent study by (Ajzen, Icek, 1985; Ajzen, 1991), (Chu \& Chiu, 2003), (Miafodzyeva, 2012), (Xu, Ling, Lu, \& Shen, 2017), (Strydom, 2018),(Kumar, 2019) and (Wang, Ren, Dong, Zhang, \& Wang, 2019), human actions are driven by three (3) kinds of belief. The first is about the possible outcome of specific behaviour and the evaluations of such effect (behavioural view). Secondly is concerned with normative expectation of others' significance and motivation to comply with such expectation (normative beliefs) and is concerned with the absence or presence of other factors that may disrupt the performance of behaviour and perceived power such as factors (control beliefs).

An individual's capability of a particular behaviour is determined by the individual's intent to perform that behaviour. Beliefs inform attitudes; norms informed by normative beliefs and motivation to comply, and assumptions inform perceived behaviour control about an individual's possession of the opportunities and resources needed to engage in the behaviour (Miafodzyeva, 2012). Generally, the more knowledge about recycling and its impact on the natural world, the more likely a household will practice.

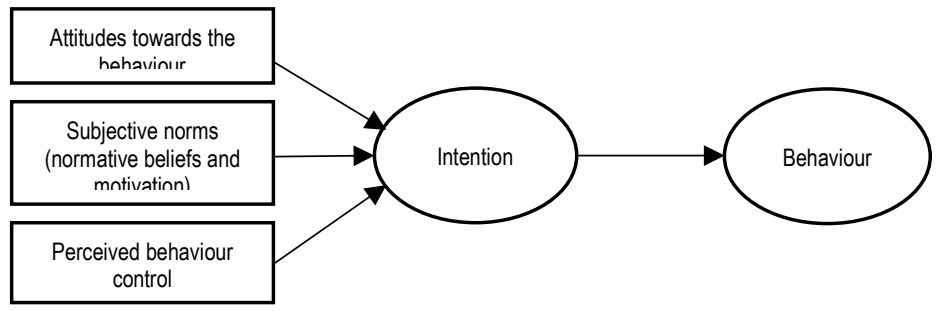

Figure 1: A basic model of TPB Framework adopted from Ajzen (1991)

(Source: Ajzen (1985,1991), Chu \& Chiu, (2003), Miafodzyeva, (2012), Xu, Ling, Lu, \& Shen, (2017), Strydom, (2018), Kumar, (2019) and Wang, Ren, Dong, Zhang, \& Wang, (2019) 


\subsection{Factors of Recycling Behaviour: The Extended TPB Framework}

In recycling, diverse behaviours are explained using an extended TPB model to construct variables such as policy regulation, incentives, facilitating conditions, subject norm, moral norm, self-efficacy, and awareness of consequences (Knickmeyer, 2020). A person's attitude toward targeted behaviour begins with experience, understanding, knowledge, and conception about individual behaviour. As a result, attitude can be determined by various factors. Ong, Fearnley and Chia (2019) studied that five elements measure the structure of variables. There are behavioural measures, social-psychological measures, knowledge of recycling measures, social structural measures, and situational factors. A study by MiliutePlepiene, Hage, Plepys, \& Reipas (2016) identified four types of factors shaping household recycling behaviour: socio-psychological techno-organisational, socio-demographic, and other study-specific characteristics. Hence, this study has determined the TPB framework's extended research model to be used as basis variables to measure the urban household's behaviour. These five factors in measuring factors about issues and problem of domestic waste recycling practice.

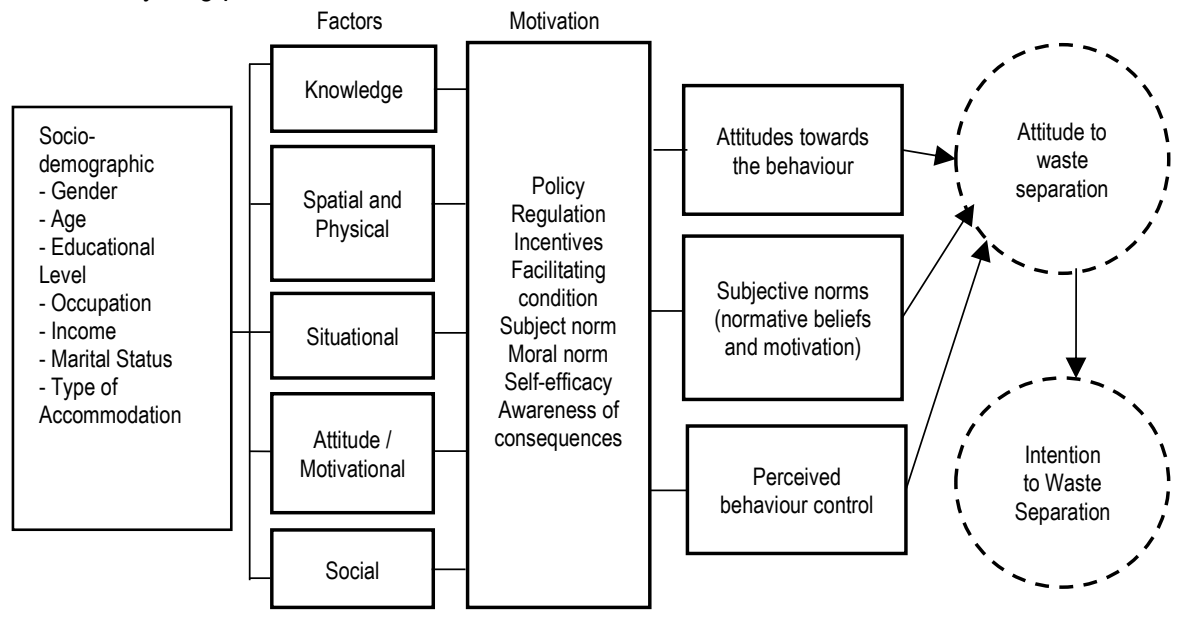

Figure 2: Extended research model of TPB Framework

(Source: Ajzen (1985,1991), Chu \& Chiu, (2003), Miafodzyeva, (2012), Miliute-Plepiene et al., (2016), Xu, Ling, Lu, \& Shen, (2017), Strydom, (2018), Kumar, (2019), Wang, Ren, Dong, Zhang, \& Wang, (2019), and Ong et al., (2019)

\subsection{Methodology}

The research undertakes primary data collection using a household questionnaire survey. This preliminary survey conducted in Shah Alam, Selangor densely involved six (6) suburban areas: Seksyen 2, 6, 7, 8, 10, and 11. The study area is one of the significant as the highest urban populated state. Shah Alam City Council (MBSA) had implemented various programmes and initiatives to ensure that the city was kept clean and well 
maintained, thus educating the local population on the importance of recycling. The criteria for site selection are basically on reclamation title as "Projek Zon Bersih." MBSA has located a recycling centre at Seksyen 2, 6, 7, and 11, a prominent area to evaluate the household behaviour towards domestic waste recycling. The neighbourhoods were chosen consists of landed and high-rise property comprised of low cost, medium, and high-cost houses, and the site survey set-up among those properties stated in the figures below.

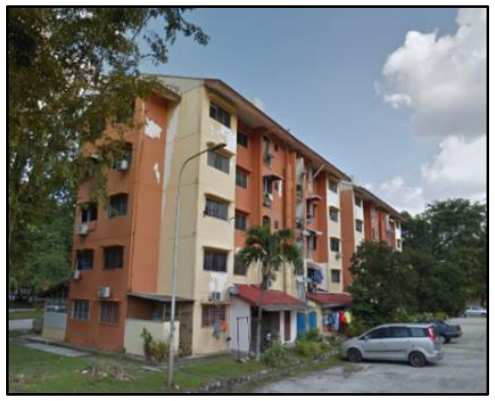

Figure 3: Flat PKNS, Seksyen 6 (Source: Researcher, 2020)

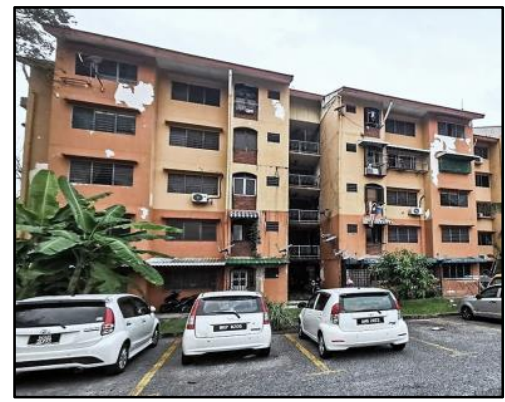

Figure 5: Flat PKNS, Seksyen 8 (Source: Researcher, 2020)

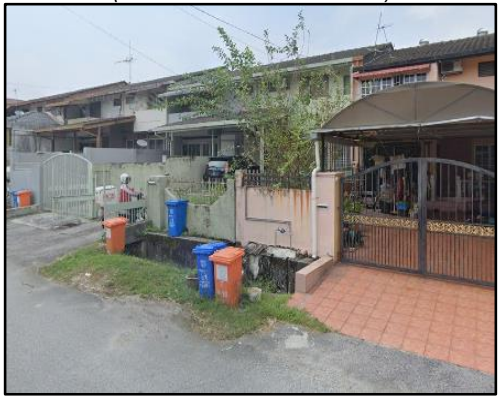

Figure 7: Jalan Sari, Seksyen 10 (Source: Researcher, 2020)

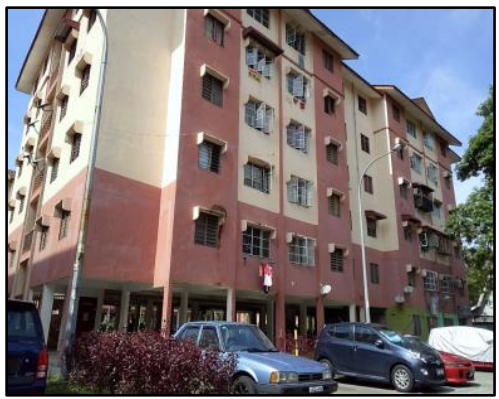

Figure 4: Flat PKNS, Seksyen 7 (Source: Researcher, 2020)

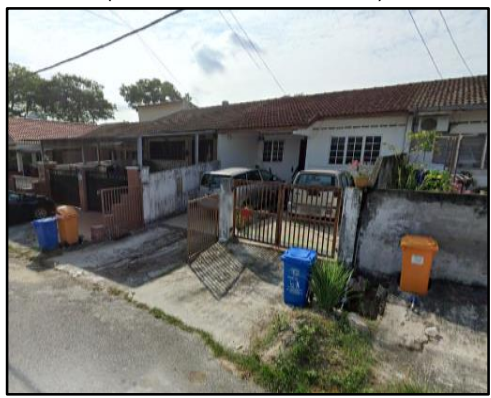

Figure 6: Jalan Bunga Raya, Seksyen 2

(Source: Researcher, 2020)

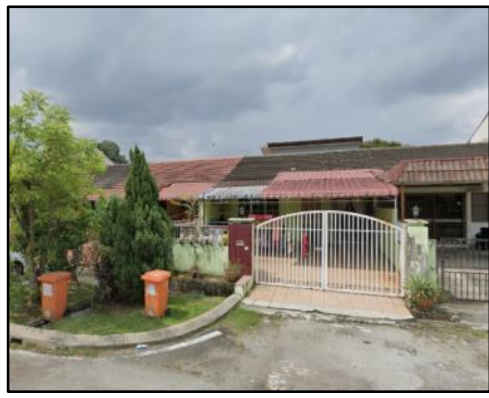

Figure 8: Jalan Gelang, Seksyen 11

(Source: Researcher, 2020) 
The sample size determined for the preliminary survey is 100 respondents; however, due to constraints in terms of respondent's willingness to participate in the study and due to unoccupied units during data collection, the survey managed to get only ninety respondents using a convenience sampling method. The survey was conducted in three days, Friday, Saturday, and Sunday (in September 2020) started at 8 a.m. until 7 p.m. each day. The researcher distributed the questionnaire samples to each selected Seksyen accordingly. The first unit of the housing block was randomly chosen; if there is a vacant and unwilling household to participate in the survey, the questionnaire was distributed to the next houses.

Measurement on household recycling behaviour can be obtained using five measures mentioned in Table 1 to derive the factors that constituted behavioural measures:

1. Behavioural measures constructed three (3) scales, namely various recycling scale or other study-specific factors.

2. Frequent recyclers indicate how often an individual prepares or separates domestic household waste for recycling.

3. The variety reuse scale refers to a similar set of household items and materials, which imply that things are neither sold, donated, nor discarded into waste stream or roadside.

4. Social-psychological measures social pressure in terms of (dis)approval from others (friends, neighbours, and relatives), awareness, rules, and regulation (Miliute-Plepiene et al., 2016),

5. Knowledge of recycling measures by understanding the household's level of experience and awareness of what materials are appropriate for recycling

Besides, social structural measures as determined under the provisions on age, educational, household incomes, gender, profession, and accommodation type described by Miliute-Plepiene, etc. (2016) as well as socio-demographic factors. Lastly, situational factors included measuring the quality of recycling infrastructures, location of collection bins, frequency of collection, the attractiveness of collection points, and ease of the recycling process. The data gathered were statistically analysed using SPSS. The mean score was used to analyse the data and Mann-Whitney $U$ Test analysis to measure the correlation between those living in landed and high-rise houses.

Table 1. Theory Planned Behaviour Factors and related variables to measure

\begin{tabular}{|c|c|}
\hline TPB Factors & Variables \\
\hline Knowledge & Level on knowledge about natural environmental \\
\hline Spatial and Physical & Awareness of waste management \\
\hline Situational & Quality of recycling facilities, location, access and frequency of \\
\hline Attitude / Motivational & collection \\
\hline Social & Individual commitment to recycling \\
\hline & Social responsible, rules and regulations, incentives and rewards \\
\hline
\end{tabular}




\subsection{Results}

\subsection{Residents Demographic Profile}

Most landed households, and high rise respondents ( $\mathrm{N}=90)$ were female $(55.6 \%)$. About $61 \%$ of the respondents have income less than RM4849, with $30 \%$ employed as professionals. Most respondents have a Bachelor Degree and Diploma with $43.3 \%$ and $36.7 \%$ respectively. Regarding age, both respondents were mostly aged between 18 to 35 years old $(57.8 \%)$.

Table 2. Respondent's demographic profile

\begin{tabular}{|c|c|c|c|c|c|}
\hline \multirow[t]{2}{*}{ Variables } & \multirow[t]{2}{*}{ Categories } & \multicolumn{2}{|c|}{ Type of Accommodation } & \multirow{2}{*}{$\begin{array}{c}\text { Frequency } \\
\mathrm{N}=90\end{array}$} & \multirow[t]{2}{*}{$\%$} \\
\hline & & Landed & High rise & & \\
\hline \multirow[t]{2}{*}{ Gender } & Male & 27 & 13 & 40 & 44.4 \\
\hline & Female & 32 & 18 & 50 & 55.6 \\
\hline \multirow[t]{5}{*}{ Age } & $13-17$ years & 1 & 1 & 2 & 2.2 \\
\hline & $18-35$ years & 33 & 19 & 52 & 57.8 \\
\hline & $36-45$ years & 14 & 7 & 21 & 23.3 \\
\hline & $46-55$ years & 9 & 2 & 11 & 12.2 \\
\hline & $>56$ years & 2 & 2 & 4 & 4.4 \\
\hline \multirow[t]{5}{*}{ Education level } & Certificate & 7 & 8 & 15 & 16.7 \\
\hline & Diploma & 18 & 15 & 33 & 36.7 \\
\hline & Bachelors & 322 & 7 & 39 & 43.3 \\
\hline & Master & 2 & 1 & 3 & 3.3 \\
\hline & $\mathrm{PhD}$ & - & - & - & - \\
\hline Household & $<\mathrm{RM} 4,849$ & 29 & 26 & 55 & 61.1 \\
\hline \multirow[t]{2}{*}{ Income } & RM4,850-RM10,959 & 26 & 5 & 31 & 34.4 \\
\hline & $>\mathrm{RM} 10,960$ & 4 & - & 4 & 4.4 \\
\hline \multirow[t]{2}{*}{ Marital Status } & Single & 16 & 8 & 24 & 26.7 \\
\hline & Married & 43 & 23 & 66 & 73.3 \\
\hline \multirow[t]{6}{*}{ Occupation } & Professional & 21 & 6 & 27 & 30.0 \\
\hline & Technicians & 11 & 3 & 14 & 15.6 \\
\hline & Clerical Workers & 7 & 6 & 13 & 14.4 \\
\hline & Services and Sales & 10 & 5 & 15 & 16.7 \\
\hline & Machine Operator & - & 3 & 3 & 3.3 \\
\hline & Unemployed & 10 & 8 & 18 & 20.0 \\
\hline Type of & Landed Property & 59 & - & 59 & 65.6 \\
\hline Accommodation & High rise Property & - & 31 & 31 & 34.4 \\
\hline
\end{tabular}

\subsection{Approaches on Separating Domestic Waste}

The result indicates respondents living in landed properties $(n=18, N=90)$ prefer to handle and isolate their domestic waste, but not all send their household waste to recycling centres $(n=24, N=90)$. There are still those who segregate domestic waste and put it in their bins and public bins to be managed by the council. Similar to those living in high-rise property, it does not prevent them from doing recycling activities. However, a few respondents from both groups claimed that many more would partake in this activity. But, only if there are parties that provide public bins and collect from block to block since some cannot go to the recycling centre, especially for high-rise residents and distant home to the recycling centre. 


\section{Approach on Separating Domestic Waste}

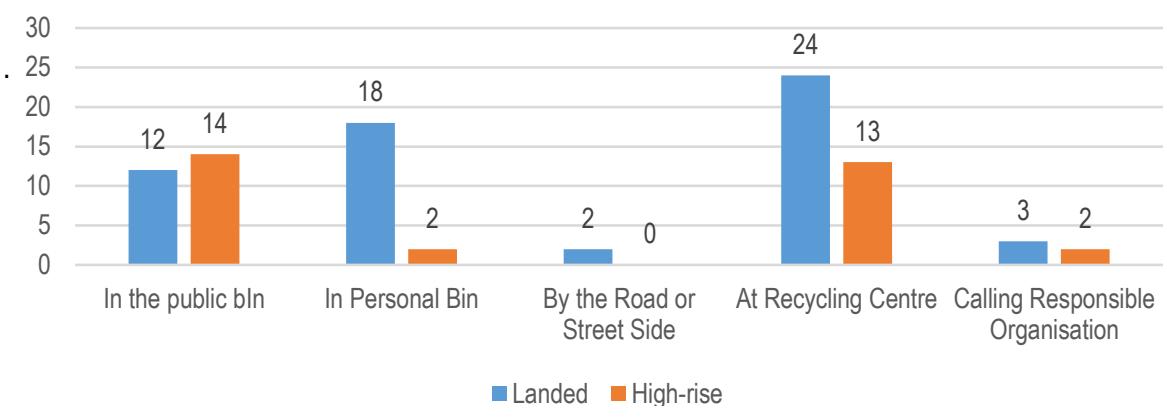

Figure 9: Approaches on separating domestic waste among landed and high-rise residents

\subsection{Problems on Managing Domestic Waste according to Occupation}

Most of them did not encounter any problems with recycling their domestic waste because they intended to do so, and the facilities provided by the council facilitated their affairs. However, a few respondents believe that recycling is difficult for them in terms of their time management and distance from houses to recycling facilities. The researcher asked several questions about the issues they encountered during the recycling activity. Due to their job considerations, some respondents claimed time constraints caused difficulty for them to isolate and conduct recycling activities daily. However, most unemployed respondents (housewives and students) have no problems managing domestic waste recycling. It showed unemployed individuals have more time to structure their household and conduct recycling activities

\section{Problems on Managing Domestic Waste Recycling}

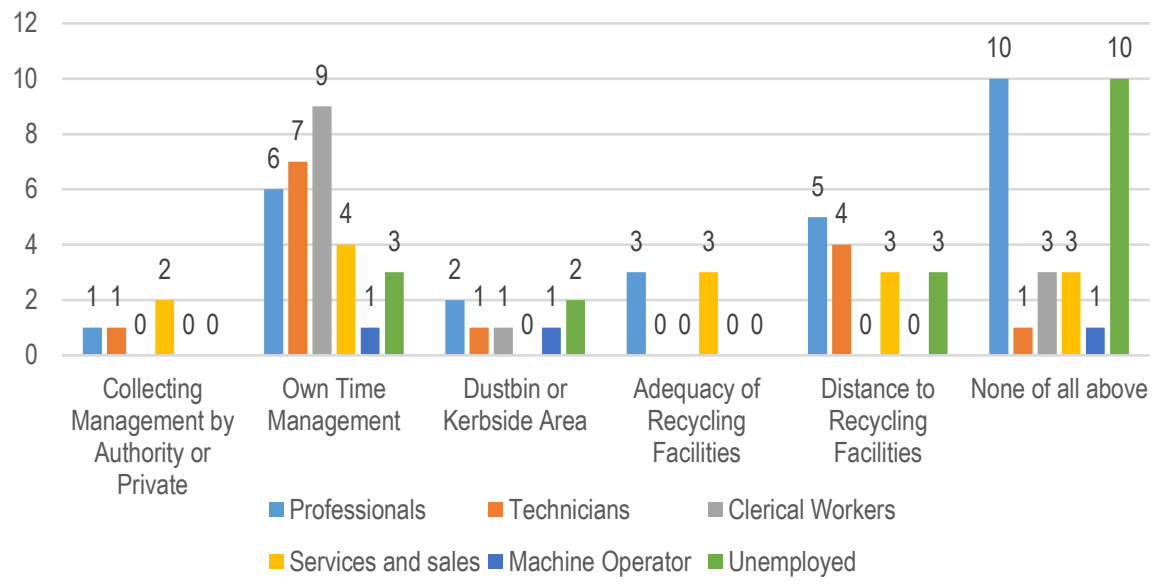

Figure 10: Problems on managing domestic waste recycling according to type of occupation among urban households. 


\subsection{Factor Analysis on Domestic Waste Recycling between Landed and High rise urban households}

Table 3 shows the summary statistic of the Mann Whitney $U$ Test of five factors. There was a significant difference in spatial and physical factor (2 variables) and situational factor (1 variable) between landed and high rise households. For the spatial and physical factor, there is a significant difference $(p<0.05)$ in perception on less provision of dustbin $(p=0.001)$ between both groups of respondents. Specifically, respondent staying at landed property ranked first (mean rank $=51.9$ ) and followed by those staying in high rise property (mean rank =33.3). Secondly, there is a significant difference in the perception of no responsible organisation's access to collect recyclable $(p=0.022)$. Similarly, those staying in landed property ranked first (mean rank $=49.9$ ) and followed by respondent staying at high rise property (mean rank $=37.05$ ). Furthermore, for situational factors, the result shows that lack of access to recycling facilities differs between both groups of respondents $(p=0.03)$. Specifically, respondent staying at landed property ranked first (mean rank = 49.6), followed by those staying in high rise property (mean rank $=37.5$ ). However, the result also shows there are no significant differences at all $(p>0.05)$ in the perception on the knowledge ( 5 variables), attitude ( 6 variables) and social ( 5 variables) between both groups of respondents. Based on the mean score, knowledge ( 5 variables), situational (4 variables), attitude ( 3 variables) and social (4 variables) between both groups of respondents are below the scale of 3 . This result indicates that respondents were agreed with issues highlighted based on factors above.

Table 3: Mean Rank and p-value of Knowledge, Spatial and Situational

\begin{tabular}{|c|c|c|c|c|c|c|c|}
\hline Factor & Variables & Respondent's & Mean & z- & ** & & \\
\hline \multirow{9}{*}{ Knowledge } & \multirow{2}{*}{$\begin{array}{l}\text { Little concern about } \\
\text { domestic recycling in } \\
\text { family }\end{array}$} & Landed & 47.02 & -.787 & .431 & Mean & 2.92 \\
\hline & & High-rise & 42.61 & & & Mean & 2.74 \\
\hline & \multirow[t]{2}{*}{$\begin{array}{l}\text { Less information in } \\
\text { the neighbourhood } \\
\text { community }\end{array}$} & Landed & 45.97 & -.244 & .807 & Mean & 2.51 \\
\hline & & High-rise & 44.61 & & & Mean & 2.42 \\
\hline & \multirow{2}{*}{$\begin{array}{l}\text { Relatives and } \\
\text { friends rarely carry } \\
\text { out domestic waste } \\
\text { recycling }\end{array}$} & Landed & 46.18 & -.353 & .724 & Mean & 2.76 \\
\hline & & High-rise & 44.21 & & & Mean & 2.68 \\
\hline & \multirow{3}{*}{$\begin{array}{l}\text { Authority did not } \\
\text { provide information } \\
\text { and recycling } \\
\text { program }\end{array}$} & Landed & 43.48 & -1.054 & .292 & Mean & 2.29 \\
\hline & & High-rise & 49.34 & & & Mean & 2.48 \\
\hline & & Landed & 44.09 & & & Mean & 2.37 \\
\hline
\end{tabular}


Yakob, H., et.al. / Asian Journal of Environment-Behaviour Studies (ajE-Bs), 5(17) Sep / Dec 2020 (pp.15-31)

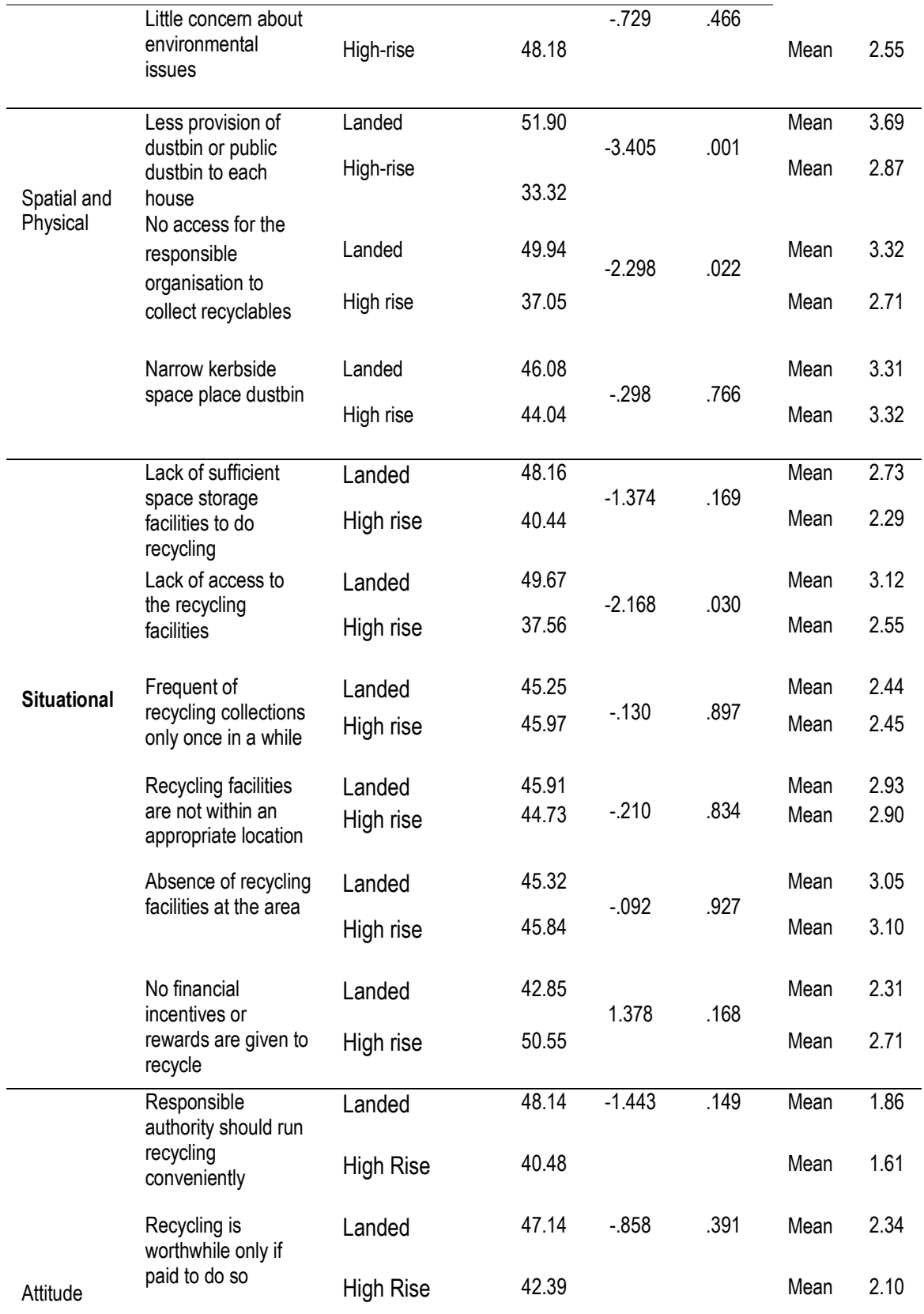


Yakob, H., et.al. / Asian Journal of Environment-Behaviour Studies (ajE-Bs), 5(17) Sep / Dec 2020 (pp.15-31)

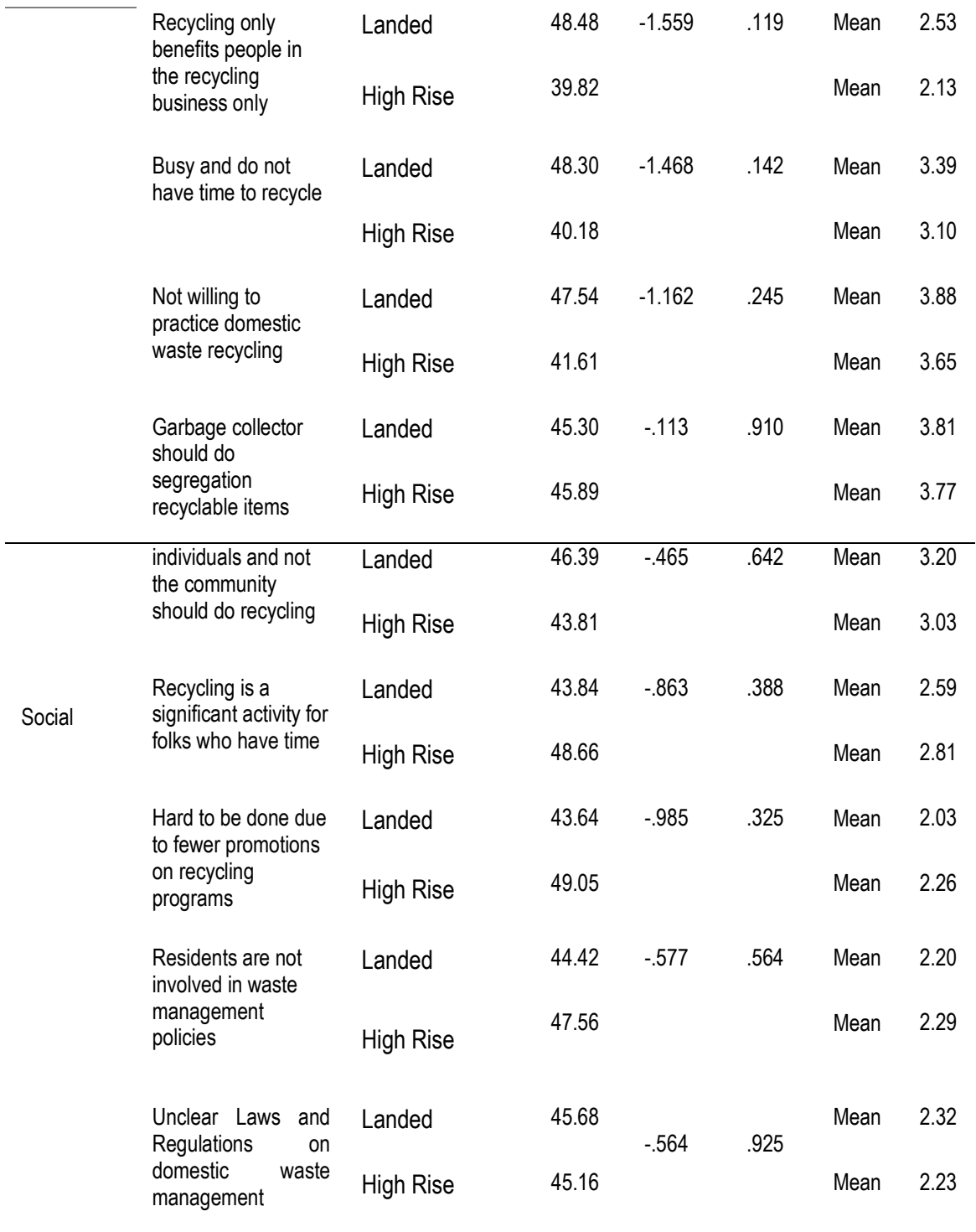

${ }^{*}$ Significant level at 0.05 


\subsection{Discussion}

\subsection{Human Behaviours Characteristic of Domestic Waste Recycling}

The urban housing areas in Shah Alam consist of two (2) types: landed and high rise property. Most apartment building only has recycling bins at the foot of the block or are located a distance away from established collection centres for recycling. Compared to landed property residents, this resulted in high-rise residents getting less access to recycling services. This findings supported by Jesson, Pocock, \& Stone, (2014), in apartment buildings, waste disposal systems raise a barrier to recycling participation. Most unemployed responders had not many facing problems in doing recycling activities than those who are working. This behaviour has been explained by Becker \& Lindhqvist (2014) 's statement that recycling is among these environmental activities that are relatively easy to carry out, compared to other activities such as reducing car use, water or meat consumption. Hence, recycling can be considered an activity where one can easily contribute to society without the high cost of time and effort. As unemployed have more time available, this recycling activity presents a rewarding opportunity. However, inactivity among this group was reported as a discouraging factor that would defeat the argument of having more time available for recycling activities. It was mentioned that unemployed individuals present good knowledge on what and how to recycle. This situation could mean that this group particularly needs support in motivating this activity and less focus on recycling issues.

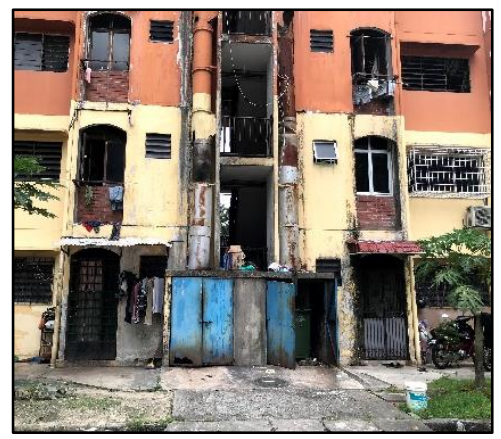

Figure 11: Recycling bin located at the foot of the block in Seksyen 8

(Source: Researcher, 2020)

\subsection{Significant Difference in Domestic Waste Recycling Factors}

There were significant differences in perception of less dustbin provision between respondents living in landed and high rise property. This situation is because most of the landed property in the study area has been provided with a domestic waste bin (blue and orange coloured) in each of Zon Bersih neighbourhood. Satisfaction can be related to the 
factors associated with the quality of the service and quality of the product, such as the number of containers (Tabernero, Hernández, Cuadrado, Luque, \& Pereira, 2015). Similarly, to the perception of lack of access to domestic recycling facilities and access to collect household waste from responsible agencies. Majority of respondents living in landed property do not have much problem on the issue as they have easy access to recycling centre compared to those living in high rise property. Rispo, Williams, \& Shaw support this result, high dense households were expected to travel to recycling centres which are quite challenging to practice.

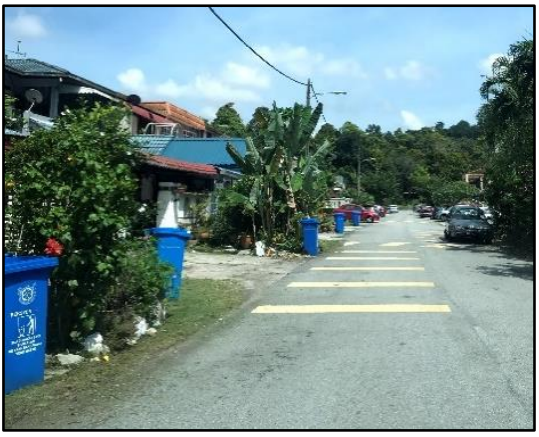

Figure 12: State of waste landed houses, Seksyen 6

(Source: Researcher, 2020)

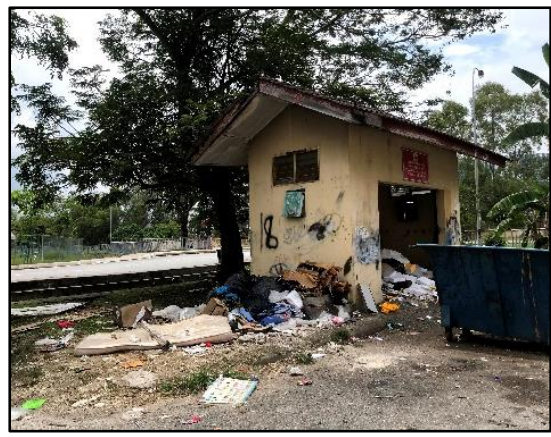

Figure 13: Overflowing dumpster at high rise houses, Seksyen 7 (Source: Researcher, 2020)

\subsection{Conclusion and Recommendations}

This preliminary study is intended to measure factors that contribute to human behaviours towards domestic waste recycling among urban household in Shah Alam before the actual survey is conducted. The study has its limitation where it focussed on domestic waste produced by households embeds among urban residents and site study within MBSA authority only which is Planning Block 1 . The sample size is also smaller, which might affect the result of findings, especially in analysing the significant differences between two (2) groups. This study's outcome is expected to be used as fundamental data to carry along to the next level of the primary research. Further research can be detailed to measure the relationship between age, gender, and educational status, contributing to participation in recycling activities. This study has a considerable amount of benefits in meeting the government's need and encouraging human lives and environment protection. The study is significant as it is incorporate the household's role and responsibilities in assessing the local government to manage domestic waste.

\section{Acknowledgements}

The authors would like to express our gratitude to the Faculty of Architecture, Planning and Surveying, Universiti Teknologi MARA (UiTM); and the Ministry of Higher Education 
Malaysia through Fundamental Research Grant Scheme- RACER (600-IRMIS/FRGSRACER 5/3 (003/2019) for their generous contribution towards this research.

\section{Article Contribution to Related Field of Study}

As the Malaysian Government had imposed its many initiatives to improve the impact of domestic waste disposal, this study initiated to respond to the global need to protect the soil and water from pollution and sustain the resources. It is also to meet the government's strategy in "strengthening the enabling environment for green growth" through enhancing awareness to create a shared responsibility.

\section{References}

Abas, M. A. (2014). Municipal Solid Waste Management in Malaysia : an Insight Towards Sustainability. (May). https://doi.org/10.13140/2.1.1774.6246

Ajzen, Icek. (1985). From intentions to actions: A theory of planned behaviour. Action Control, 11-39.

Ajzen, I. (1991). The theory of planned behaviour. Organizational Behavior and Human Decision Processes, 50(2), 179-211. https://doi.org/10.1016/0749-5978(91)90020-T

Al Mamun, A., Mohiuddin, M., Ahmad, G. Bin, Thurasamy, R., \& Fazal, S. A. (2018). Recycling intention and behaviour among low-income households. Sustainability (Switzerland), 10(7), 1-22.

https://doi.org/10.3390/su10072407

Becker, N., \& Lindhqvist, T. (2014). Increasing High Recycling Rates management Supervisors. (September). https://doi.org/10.13140/RG.2.2.29133.33769

Behzad, N., Ahmad, R., Saied, P., Elmira, S., \& Bin, M. M. (2011). Challenges of solid waste management in Malaysia. Research Journal of Chemistry and Environment, 15(2), 597-600.

Chu, P. Y., \& Chiu, J. F. (2003). Factors influencing household waste recycling behaviour: Test of an integrated model. Journal of Applied Social Psychology, 33(3), 604-626. https://doi.org/10.1111/j.15591816.2003.tb01915.x

Environmental, T., \& Agency, P. (2015). Municipal Solid Waste.

Fauziah, S. H., \& Agamuthu, P. (2012). Trends in sustainable landfilling in Malaysia, a developing country. Waste Management and Research, 30(7), 656-663. https://doi.org/10.1177/0734242X12437564

Jereme, I., Siwar, C., \& Alam, M. (2015). Waste Recycling in Malaysia: Transition From Developing To Developed Country. Indian Journal of Education and Information Management, 4(1), 1-14-14.

https://doi.org/10.31235/osf.io/xgf8k

Jesson, J. K., Pocock, R., \& Stone, I. (2014). Barriers to recycling: A review of evidence since 2008 M-E-L Research A Report for WRAP. (December 2014), 2008-2013. Retrieved from www.wrap.org.uk

Kawasaki. (2014). Household Waste PP1. 2020. 
Knickmeyer, D. (2020). Social factors influencing household waste separation: A literature review on good practices to improve the recycling performance of urban areas. Journal of Cleaner Production, 245, 118605. https://doi.org/10.1016/j.jclepro.2019.118605

Kumar, A. (2019). Exploring young adults' e-waste recycling behaviour using an extended theory of planned behaviour model: A cross-cultural study. Resources, Conservation and Recycling, 141(June 2018), 378-389. https://doi.org/10.1016/j.resconrec.2018.10.013

Miafodzyeva, S. (2012). Understanding the Recycling Behaviour of Householders in Multicultural Urban Areas: Case Study Järva, Stockholm.

Retrieved from https://www.diva-portal.org/smash/get/diva2:556893/FULLTEXT01.pdf

Miliute-Plepiene, J., Hage, O., Plepys, A., \& Reipas, A. (2016). What motivates households recycling behaviour in recycling schemes of different maturity? Lessons from Lithuania and Sweden. Resources, Conservation and Recycling, 113, 40-52. https://doi.org/10.1016/j.resconrec.2016.05.008

Ong, C., Fearnley, L., \& Chia, S. B. (2019). Towards a sustainable future: a holistic inquiry of waste management behaviours of Singapore households. International Journal of Sustainable Development and World Ecology, 26(7), 583-596. https://doi.org/10.1080/13504509.2019.1631898

Othman, A. R., \& Yuhaniz, M. (2012). Recycle of Domestic Waste among Terrace House Residents in Shah Alam. Procedia - Social and Behavioral Sciences, 50(July), 884-898.

https://doi.org/10.1016/j.sbspro.2012.08.090

Rispo, A., Williams, I. D., \& Shaw, P. J. (2015). Source segregation and food waste prevention activities in highdensity households in a deprived urban area. Waste Management, 44, 15-27.

https://doi.org/10.1016/j.wasman.2015.04.010

Strydom, W. F. (2018). Applying the theory of planned behavior to recycling behavior in South Africa. Recycling, 3(3). https://doi.org/10.3390/recycling3030043

Tabernero, C., Hernández, B., Cuadrado, E., Luque, B., \& Pereira, C. R. (2015). A multilevel perspective to explain recycling behaviour in communities. Journal of Environmental Management, 159, 192-201. https://doi.org/10.1016/j.jenvman.2015.05.024

Teo, C. B. (2017). Recycling Behaviour of Malaysian Urban Households and Upcycling Prospects. (March).

Thomas, C., \& Sharp, V. (2013). Understanding the normalisation of recycling behaviour and its implications for other pro-environmental behaviours: A review of social norms and recycling. Resources, Conservation and Recycling, 79, 11-20. https://doi.org/10.1016/j.resconrec.2013.04.010

Umar, S., Sehab, P., \& Yagnik, P. (2018). 3R's Concept: Reduce, Reuse \& Recycle. Sardar Patel College of Engineering , Anand , India. International Journal for Scientific Research \& Development, 6(03), 57-59.

Wang, B., Ren, C., Dong, X., Zhang, B., \& Wang, Z. (2019). Determinants shaping willingness towards on-line recycling behaviour: An empirical study of household e-waste recycling in China. Resources, Conservation and Recycling, 143(January 2019), 218-225.

https://doi.org/10.1016/j.resconrec.2019.01.005

Xu, L., Ling, M., Lu, Y., \& Shen, M. (2017). Understanding household waste separation behaviour: Testing the roles of moral, past experience, and perceived policy effectiveness within the theory of planned behaviour. Sustainability (Switzerland), 9(4). https://doi.org/10.3390/su9040625 
Yakob, H., et.al. / Asian Journal of Environment-Behaviour Studies (ajE-Bs), 5(17) Sep / Dec 2020 (pp. 15-31)

Zen, I. S., Noor, Z. Z., \& Yusuf, R. O. (2014). The profiles of household solid waste recyclers and non-recyclers in Kuala Lumpur, Malaysia. Habitat International, 42, 83-89.

https://doi.org/10.1016/j.habitatint.2013.10.010 